GEOPHYSICAL RESEARCH LETTERS, VOL. 17, NO. 7, PAGES 989-991, JUNE 1990

\title{
THE GREAT MACQUARIE RIDGE EARTHQUAKE OF 1989: INTRODUCTION
}

\author{
Larry J. Ruff, Guest Editor
}

Department of Geological Sciences, The University of Michigan.

On May 23, 1989, a great earthquake struck a remote region of the South Pacific Ocean between New Zealand and Antarctica. The nearby islands are Macquarie Island, about $300 \mathrm{~km}$ south of the epicenter, and Campbell Island, almost $600 \mathrm{~km}$ east of the epicenter; the latter experienced shaking with intensity V. Fortunately, both islands are sparsely inhabited and little damage or injuries were reported. In addition, only relatively small tsunamis were recorded on tide records in Australia. We can all take comfort from the fact that this great earthquake had little impact upon the activities of the nearby communities, yet it has had substantial impact within the global seismological and tectonic communities. With respect to seismology, the 1989 Macquarie Ridge event is the largest earthquake of the decade. Moreover, this earthquake provided a "test" for the rapid exchange of digital seismograms from the new-generation global seismographic stations. With respect to tectonics, this earthquake occurred in a somewhat unusual tectonic setting where a new subduction zone may be starting.

A special session on the great 1989 Macquarie Ridge earthquake was held at the 1989 Fall meeting of the American Geophysical Union. This special section is based largely on papers presented at the AGU meeting, in particular the papers by: Ekstrom \& Romanowicz, Satake \& Kanamori, Tichelaar \& Ruff, Anderson, Park, and Gross \& Chao. In addition, this special issue contains contributions from Braunmiller \& Nabelek, and Houston. These eight papers cover many different aspects of the great Macquarie Ridge earthquake, i.e., moment tensor, focal mechanism, source time function, rupture process, stress-drop, ultra-long period characteristics, and seismotectonics. Rather than preview the research contributions in the following papers, I turn my focus to the seismological environment and tectonic context in which this great earthquake occurred.

\section{Seismological aspects}

First and foremost, the 1989 Macquarie Ridge earthquake is the largest earthquake of the 1980's (Table 1 and Figure 1). To be more specific, it is the largest earthquake, as measured by seismic moment, since the great underthrusting earthquake of December 12,1979, along the Colombia-Ecuador subduction zone. An interesting feature of seismicity in the 1980's is the large number of strikeslip earthquakes (Table 1).

The great size of the 1989 Macquarie Ridge earthquake was immediately apparent in the preliminary $M_{S}$ estimates

Copyright 1990 by the American Geophysical Inion.

Paper number 90GL01163

0094-8276/90/90GL-01163\$03.00 of 8 or larger. Since the daily seismic activity is now available through electronic mail from the NEIC, many seismologists were soon aware of this event. Even more impressive is how quickly waveform data and preliminary estimates of focal mechanism and seismic moment were obtained. New generation IRIS digital seismographs were operating in Pasadena, CA and "Harvard", MA; the dial-up capability of these stations allow the entire seismological community immediate access to these waveforms. In fact, Dr. Dziewonski and coworkers (Harvard) and Drs. Kanamori and Satake (Caltech) used this capability to immediately analyze longperiod waves for preliminary estimates of the moment tensor [see EOS news article by W. Maggs, 1989]. Unfortunately, both of these IRIS stations are at the same azimuth with respect to the Macquarie Ridge. The importance of real-time access to a digital global network is thus quite apparent. Indeed, Drs. Romanowicz and Ekstrom (IPG, Paris) used the capability of rapid access to several GEOSCOPE stations to determine a well-constrained moment tensor for the Macquarie Ridge earthquake [see EOS article by Romanowicz and Ekstrom, 1989].

As a personal testimony, I was fortunate to be visiting the University of Washington when the Macquarie Ridge earthquake occurred. There, I was able to use a prototype version of the "gopher" program, developed by Dr. Malone (U. of W.) for IRIS. This program, now implemented at the IRIS data management center, displays and sends all available waveform data through an internet connection. Later, I received nearly the full complement of GDSN waveform data via electronic mail, courtesy of $M$. Zirbes (USGS). A tape with GEOSCOPE data followed shortly after that, courtesy of Dr. Romanowicz (IPG, Paris). While a special GDSN event tape for the Macquarie Ridge earthquake was distributed in a relatively short time after the earthquake, many digital seismograms from global stations had already been received and analyzed by seismologists scattered about the world. The 1989 Macquarie Ridge earthquake not only ends the 1980's with impact, but it starts the 1990's as an example of rapid international digital data exchange.

\section{Tectonic aspects}

In addition to its great size, the 1989 Macquarie Ridge earthquake is interesting due to its tectonic setting. The Macquarie Ridge complex (MRC) stretches more than 1500 $\mathrm{km}$ between South Island, New Zealand, and the PacificAustralia-Antarctica triple junction. The MRC consists of a roughly continuous bathymetric high with distinct troughs that occur on alternate sides of the ridge (see Figure 2, and cover figure). Plate reconstructions and geophysical studies indicate that the Macquarie Ridge has had a complicated 
Table 1. The twelve largest earthquakes of the 1980 's

\begin{tabular}{|c|c|c|c|c|c|}
\hline Date & Region & $\mathrm{M}_{\mathrm{S}}$ & $\begin{array}{c}\mathrm{M}_{0} \\
\left(10^{20} \mathrm{Nm}\right)\end{array}$ & Faulting & $\begin{array}{r}\text { Tectonic } \\
\text { setting }\end{array}$ \\
\hline 23 May 1989 & Macquarie Ridge & 8.2 & 14 & strike-slip & transitional \\
\hline 19 Sep 1985 & Mexico & 8.1 & 11 & thrust & subduction \\
\hline 3 Mar 1985 & Chile & 7.8 & 10 & thrust & subduction \\
\hline 7 May 1986 & Aleutian Is. & 7.7 & 10 & thrust & subduction \\
\hline 30 Nov 1987 & Gulf Alaska & 7.6 & 7 & strike-slip & intraplate? \\
\hline 6 Mar 1988 & Gulf Alaska & 7.6 & 5 & strike-slip & intraplate? \\
\hline $17 \mathrm{Jul} 1980$ & Santa Cruz Is. & 7.9 & 5 & thrust & subduction \\
\hline $18 \mathrm{Mar} 1983$ & Solomon Is. & 7.6 & 5 & thrust & intraplate? \\
\hline 26 May 1983 & West Honshu & 7.7 & 5 & thrust & back-arc thrusting \\
\hline 25 May 1981 & Macquarie Ridge & 7.6 & $5^{*}$ & strike-slip & transitional \\
\hline 20 Oct 1986 & Kermadec Is. & 8.1 & 5 & strike-slip/thrust & $?$ \\
\hline 30 Nov 1983 & Chagos Ridge & 7.6 & 4 & normal & transitional? \\
\hline
\end{tabular}

$\mathrm{M}_{\mathrm{S}}$ (surface wave magnitude) is from NEIS. $\mathrm{M}_{0}$ (seismic moment) is from Harvard CMT catalog [see, e.g., Dziewonski and Woodhouse, 1983], except for *, which is from Ruff et al. [1989]. The Harvard CMT moment for 25 May 1981 is $3 \times 10^{20} \mathrm{Nm}$.

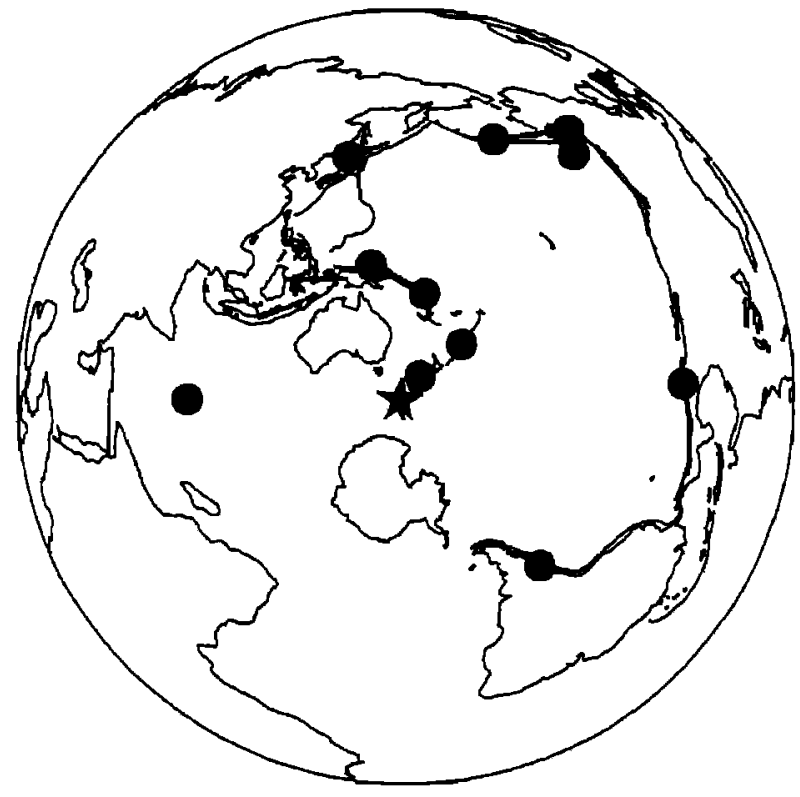

Fig. 1. The twelve largest earthquakes of the 1980's, plotted as dots. The azimuthal equidistant projection is centered on the 1989 Macquarie Ridge earthquake (star), the largest event of the decade.

history over the past twenty million years or so. These complications are partly reflected in the tectonic evolution of New Zealand [see, e.g., Walcott, 1978]. The northern MRC has switched from a divergent boundary to its present-day oblique convergence [see, e.g., Hayes and Talwani, 1972; Falconer, 1972; Molnar et al., 1975; Weissel et al., 1977; Stock and Molnar, 1982]. The south- ernmost MRC, i.e. the Hjort trench segment, probably formed in an oblique convergent environment at the Pacific-Australia-Antarctica triple junction [see Weissel et al., 1977; Ruff et al., 1989]. The mixture of thrust and right-lateral strike-slip earthquakes along the MRC is roughly consistent with global determinations of the Pacific-Australia rotation pole (see Figure 2). As one caveat, there are some inconsistencies with transform azimuths along the Australia-Antarctica plate boundary just to the west of the MRC [De Mets et al., 1988]; perhaps the "Tasman spur" (the narrow extension of the Australia plate along the west side of the MRC) is not a perfect rigid extension of the Australia plate.

Macquarie Ridge earthquakes show an interesting response to oblique convergence: intermixed thrust and strike-slip earthquakes on adjacent, but not identical, faults. Ruff et al. [1989] focused on this relationship in the rupture area of the large 1981 strike-slip earthquake (see Table 1). They noticed that the 1981 event was much larger than the preceding thrust events, which apparently did not occur on a single coherent underthrusting fault plane. Ruff et al. then speculated that this "dual rupture mode" was a temporary response due to the transitional tectonic environment, and that subduction initiation is occurring throughout the MRC. Geoid anomalies across the MRC, as measured by SEASAT, offer some support for these ideas [Ruff and Cazenave, 1985]. Of course, one of the best tests of a seismotectonic hypothesis is to have another large earthquake. Two of the following papers specifically address the impact of the 1989 earthquake on the MRC seismotectonics. Certainly one important tectonic aspect of the 1989 Macquarie Ridge earthquake is whether it confirms or denies the notion of subduction initiation in the MRC. However, perhaps it is more important that this great earthquake attracts the focus of seismologists and geophysicists to this fascinating region and the general problem of subduction initiation. 


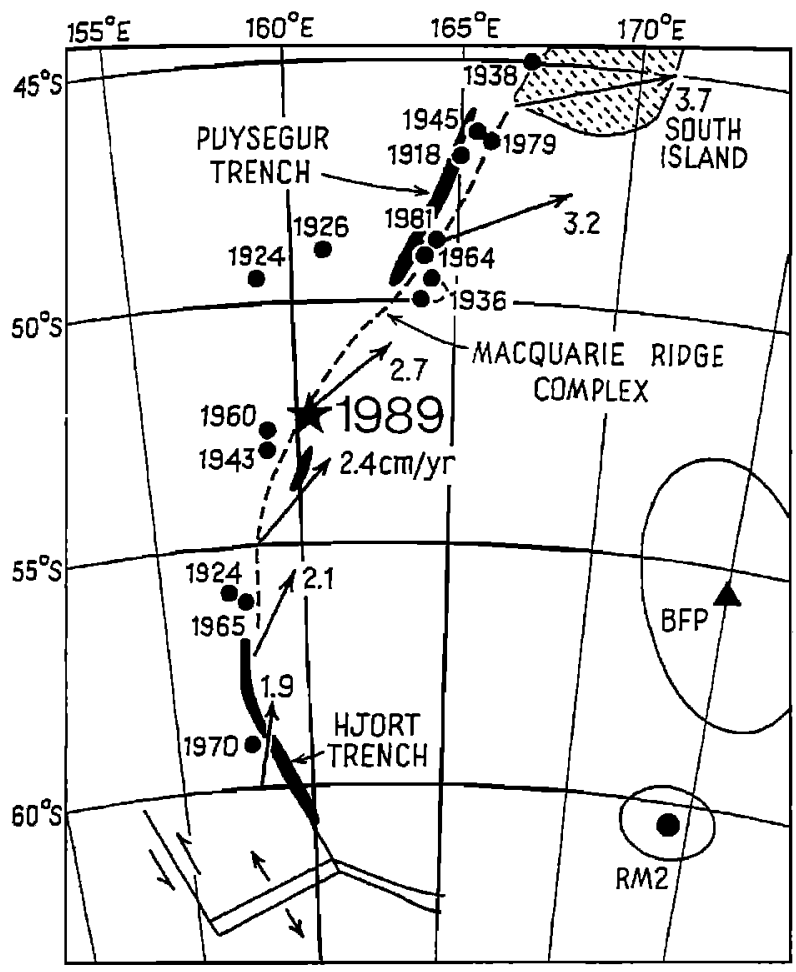

Fig. 2. Simplified tectonics and seismicity of the Macquarie Ridge complex. Large earthquakes (magnitude greater than 7) are plotted as dots with the year of their occurrence. The great earthquake of 1989 is plotted as a star. Two Pacific-Australia plate motion rotation poles and their error ellipses are plotted: the best-fitting pole (BFP) and the global model pole (RM2) from Minster and Jordan [1978]. The motion of the Australia plate relative to the Pacific plate along the Macquarie Ridge is shown by the vectors, based on the RM2 pole with velocity in $\mathrm{cm} / \mathrm{yr}$. The bathymetric rise of the Macquarie Ridge is schematically plotted as the dashed line, while the troughs are indicated by the solid regions. The spreading segment and Balleny transform fault between the Antarctica and Australia plates are also sketched. The Pacific-Antarctica-Australia triple junction is located at $61.5^{\circ} \mathrm{S}, 161^{\circ} \mathrm{E}$. (From Ruff et al, 1989.)

Acknowledgments. I thank Bart Tichelaar for his enthusiasm and help with the AGU special session and this GRL special issue. I thank Steve Malone, Madeleine Zirbes, Barbara Romanowicz, and Goran Ekstrom for their help with various aspects of data dissemination. A special thanks to: all contributors to this special issue, the GRL staff, and to the reviewers for their careful and timely comments. Earthquake studies at the University of Michigan are supported by the National Science Foundation (EAR8720935).

\section{References}

DeMets, C., R. Gordon, and D. Argus, Intraplate deformation and closure of the Australia-Antarctica-Africa plate circuit, J. Geophys. Res., 93, 11877-11897, 1988.

Dziewonski, A., and J. Woodhouse, An experiment in systematic study of global seismicity: centroid moment tensor solutions for 201 moderate and large earthquakes of 1981, J. Geophys. Res., 88, 3247-3271, 1983.

Falconer, R., The Indian-Antarctic-Pacific triple junction, Earth Planet. Sci. Lett., 17, 151-158, 1972.

Hayes, D., and M. Talwani, Geophysical investigation of the Macquarie Ridge Complex, In: Antarctic Oceanography II, edited by D. Hayes, pp 211-234, Antarctic Research Series 19, AGU, 1972.

Maggs, W., Labor pains at subduction's birth, EOS Trans. AGU, 70, \#24 (June 13), 650, 1989.

Minster, J., and T. Jordan, Present-day plate motions, J. Geophys. Res., 83, 5331-5354, 1978.

Molnar, P., T. Atwater, J. Mammerickx and S.M. Smith, Magnetic anomalies, bathymetry, and the tectonic evolution of the South Pacific since the late Cretaceous, Geophys. J. R. Astr. Soc., 40, 383-420, 1975.

Romanowicz, B., and G. Ekstrom, Macquarie earthquake of May 23, 1989, EOS Trans. AGU, 70, \#28 (July 11), $700,1989$.

Ruff, L., and A. Cazenave, SEASAT geoid anomalies and the Macquarie Ridge complex, Phys. Earth Planet. Int., 38, 59-69, 1985.

Ruff, L., J. Given, C. Sanders, and C. Sperber, Large earthquakes in the Macquarie Ridge complex: Transitional tectonics and subduction initiation, Pageoph, 129, 70 130, 1989.

Stock, J., and P. Molnar, Uncertainties in the relative positions of the Australia, Antarctica, Lord Howe, and Pacific plates since the late Cretaceous, J. Geophys. Res., 87, 4697-4714, 1982.

Walcott, R., Present tectonics and late Cenozoic evolution of New Zealand, Geophys. J. R. Astron. Soc., 52, 137-164, 1978.

Weissel, J., D. Hayes, and E. Herron, Plate tectonic synthesis: the displacements between Australia, New Zealand, and Antarctica since the late Cretaceous, Marine Geol., 25, 231-277, 1977.

Larry J. Ruff, Dept. Geological Sciences, University of Michigan, Ann Arbor, MI 48109.

(Received April 26, 1990; accepted May 4, 1990.) 